\title{
New composites based on low-density polyethylene and rice husk: Elemental and thermal characteristics
}

\author{
Muhammad Anshar ${ }^{1}$, Dahlang Tahir $^{2}$, Makhrani ${ }^{2}$, Farid Nasir Ani ${ }^{3}$, Ab Saman Kader \\ ${ }^{1}$ Department of Mechanical Engineering, State Polytechnic of Ujung Pandang, Makassar 90245, Indonesia \\ ${ }^{2}$ Department of Physics, Hasanuddin University, Makassar 90245, Indonesia \\ ${ }^{3}$ Department of Thermodynamics and Fluid Mechanics, Universiti Teknologi Malaysia, Skudai-Johor 81310, Malaysia \\ ${ }^{4}$ Marine Technology Centre, Universiti Teknolgi Malaysia, Skudai-Johor 81310, Malaysia
}

\begin{abstract}
We developed new composites by combining the solid waste from Low-Density Polyethylene in the form of plastic bag (PB) and biomass from rice husk $(\mathrm{RH})$,in the form of $(\mathrm{RH})_{\mathrm{x}}(\mathrm{PB})_{1-\mathrm{x}}(\mathrm{x}=(1,0.9,0.7,0.5))$, as alternative fuels for electrical energy sources, and for providing the best solution to reduce environmental pollution. Elemental compositions were obtained by using proximate analysis, ultimate analysis, and X-ray fluorescence spectroscopy, and the thermal characteristics were obtained from thermogravimetric analysis. The compositions of carbon and hydrogen from the ultimate analysis show significant increases of 20-30\% with increasing PB in the composite. The activation energy for RH is $101.22 \mathrm{~kJ} / \mathrm{mol}$; for $\mathrm{x}=0.9$ and 0.7 , this increases by 4 and 6 magnitude, respectively, and for $\mathrm{x}=0.5$, shows remarkable increase to $165.30 \mathrm{~kJ} / \mathrm{mol}$. The range of temperature of about $480-660^{\circ} \mathrm{C}$ is required for combustion of the composites $(\mathrm{RH})_{\mathrm{x}}(\mathrm{PB})_{1-\mathrm{x}}(\mathrm{x}=$ $(1,0.9,0.7,0.5))$ to perform the complete combustion process and produce high energy. In addition, the calorific value was determined by using bomb calorimetry, and shows value for $\mathrm{RH}$ of $13.44 \mathrm{MJ} / \mathrm{kg}$, which increases about $30-40 \%$ with increasing PB content, indicating that $\mathrm{PB}$ has a strong effect of increasing the energy realized to generate electricity.
\end{abstract}

Keywords: Elemental composition, Low-density polyethylene, Plastic bags, Rice husk, Thermal characteristics

\section{Introduction}

Clean and efficient utilization of biomass as a source of alternative energy is of major concern, and is essential for generating electricity, especially in developing countries. Indonesia as a developing country is still lacking in electrical energy supply, with electrification of around $76.56 \%$ [1]. About $23.5 \%$ of rural communities have not yet used electrical energy, due to the inability of power plants to meet the increasing power needs of the society and industry every year. More than half of the electricity suppliers in Indonesia generate their electricity from coal [2]. Coal production in Indonesia is quite large, at around $2.751 \times 10^{8}$ tons in 2010 [3]. However, continuous mining and combustion of coal as fuel damages the natural environment. On the other hand, Indonesia has abundant potential biomass resources that are environmentally friendly. The potential of rice husk (RH) in 2012 was around $1.381 \times 10^{7}$ tons, equivalent to the electrical energy potential of around $53.702 \mathrm{GWh}$, the third largest in the world after China and India [4, 5]. Nonetheless, this potential has not been exploited, and few have reported it as a source of energy [6]; it has only been used as a catalyst [7, 8], or wasted, causing environmental pollution. In Indonesia, large amounts of biomass fuels are consumed for cooking, and some biomass of low density, such as RH, is used for heating. The burning of biomass fuel is one of the most important sources of emission of CO and volatile organic matter, which not only cause severe indoor air pollution, but also contribute to regional, global, and climate forcing. Replacing traditional fuel methods with cleaner techniques are challenges in several countries, including Indonesia. Several alternative options that are expected to result in lower emission pollution than traditional burning include pellets and catalyst. However, some studies reported the preparation of $\mathrm{RH}$ as pellets or catalyst to be time-consuming and energy intensive, due to low-density biomass, generally performed under high temperature $\left(400-800^{\circ} \mathrm{C}\right)$, and long reaction time (up to 15 h) [9-11].
This is an Open Access article distributed under the terms of the Creative Commons Attribution Non-Commercial License (http://creativecommons.org/licenses/by-nc/3.0/) which permits unrestricted non-commercial use, distribution, and reproduction in any medium, provided the original work is properly cited.

Copyright (C) 2018 Korean Society of Environmental Engineers
Received July 26, 2017 Accepted February 6, 2018

${ }^{\dagger}$ Corresponding author

Email: dtahir@fmipa.unhas.ac.id

Tel: +62-411-587634 Fax: +62-411-587634

ORCID: 0000-0002-8241-3604 
$\mathrm{RH}$ is also a widely accepted alternative energy source, due to its high carbon and oxygen composition, which is fundamental for searching sources of energy [12, 13]. Direct combustion in a grate bed combustor can minimize harmful exhaust gasses by using an exhaust emission control device, which is a technique that uses $\mathrm{RH}$ as fuel for power plants to generate electricity in Thailand [12], and India [13]. Generating electricity from biomass provides significant benefits to the environment, since it produces clean energy [14].

In addition to the electrical energy shortage, Indonesia also has problems in handling municipal solid waste (MSW), particularly low-density polyethylene (LDPE) type plastic bags (PB). The average household solid waste generated in Jakarta and another big city in Indonesia is $2,416.2 \mathrm{~kg}$ per household per year, with PB (14\%) being the second largest, and increases every year by about $2-5 \%[15,16]$. PB at landfills may take tens to hundreds of years to be completely decomposed, and subsequently, those particles could contaminate the soil and water of the surrounding area [17]. In fact, PB has a calorific value (CV) of about $41.5 \mathrm{MJ} / \mathrm{kg}$ [18]. PB combustion in the grate bed combustor can be controlled by using an exhaust emission control device to minimize harmful exhaust gasses [19-21], and PB isalso used as fuel for power plants to generate electric power of about 8.9 MW in Malaysia [21-25].

Based on the fuel needed for generating electricity, and the potentials of solid waste and biomass, in this study, we developed new composites by combinations of solid waste and biomass in the form of $(\mathrm{RH})_{\mathrm{x}}(\mathrm{PB})_{1-\mathrm{x}}(\mathrm{x}=(1,0.9,0.7,0.5))$ as alternative fuels for electrical energy sources, and on the other hand, giving the best alternative solution to reduce environmental pollution. We focus in this study on discussing the effect of PB in terms of elemental composition, by using proximate analysis, ultimate analysis, and X-ray fluorescence (XRF) and thermal characteristics, including activation energy, by using thermogravimetric analysis.

\section{Materials and Methods}

\subsection{Materials Preparation}

The samples in this study are composites $(\mathrm{RH})_{\mathrm{x}}(\mathrm{PB})_{1-\mathrm{x}}(\mathrm{x}=(1$, $0.9,0.7,0.5)$ ) from $\mathrm{RH}$ and $\mathrm{PB}$ as alternative energy sources. We chose PB type LDPE identified by the logo triangle figure in the middle of the LDPE sign, which is usually used for shower curtains, packaging, films, and clamshell. After being sun-dried, $\mathrm{RH}$ and PB were cut and ground to reduce size using a mill. Raw materials were sieved to obtain uniformity of size of between 0.125 and $0.3 \mathrm{~mm}$ (for details, see [4, 22]). The physical mixing of samples was performed by weighting each raw sample to form composites $(\mathrm{RH})_{\mathrm{x}}(\mathrm{PB})_{1-\mathrm{x}}(\mathrm{x}=(1,0.9,0.7,0.5))$ by using a digital balance. The mass of composite samples was fixed at about $10 \mathrm{~g}$. The samples were mixed withstirring for $15 \mathrm{~min}$ to obtain uniform and homogeneous composites. The samples were heated at $105^{\circ} \mathrm{C}$ temperature for one hour and seven hours for PB and RH, respectively (for details, see [23]), and for composites were the weighted average time of heating of $\mathrm{RH}$ and $\mathrm{PB}$.

\subsection{Proximate Analysis, Ultimate Analysis, and Calorific Value}

The chemical compositions of composites $(\mathrm{RH})_{\mathrm{x}}(\mathrm{PB})_{1-\mathrm{x}}(\mathrm{x}=(1$, $0.9,0.7,0.5)$ ) were determined from the proximate analysis, ultimate analysis, and XRF spectroscopy. The proximate and ultimate analyses were conducted based on the Standard Methods ASTM D 3172 - D 3174, ASTM D 4239, ASTM D 5373, and ISO 565. Meanwhile, the CV was carried out by using bomb calorimeter according to the Standard Methods ASTM D.5865 (for details, see [26, 27]).

\subsection{Oxidative and Kinetic Study}

The oxidative study of the $(\mathrm{RH})_{\mathrm{x}}(\mathrm{PB})_{1-\mathrm{x}}(\mathrm{x}=(1,0.9,0.7,0.5))$ was conducted to determine the characteristics of the kinetic parameter based on the some previous studies [28-32], by using thermal gravimetric analysis (TGA) and differential thermal gravimetric (DTG). The oxidative reaction was carried out from temperature 30 to $800^{\circ} \mathrm{C}$ for about $82 \mathrm{~min}$, at a heating rate of about $10^{\circ} \mathrm{C} / \mathrm{min}$, and flow rate of air of about $50 \mathrm{~mL} / \mathrm{min}$. The Mettler test was performed on the $(\mathrm{RH})_{\mathrm{x}}(\mathrm{PB})_{1-\mathrm{x}}(\mathrm{x}=(1$, $0.9,0.7,0.5)$ ) samples, with a mass test of about 5.5-5.8 mg. The characteristics of $(\mathrm{RH})_{\mathrm{x}}(\mathrm{PB})_{1-\mathrm{x}}(\mathrm{x}=(1,0.9,0.7,0.5))$ from TGA and DTG were analyzed by using Sma4Winsoftware. A two-stage reaction kinetic scheme has been proposed for the thermal degradation (TD) of composites under an oxidative atmosphere [31], representing the DTG curves:

$$
\begin{aligned}
& \text { First stage: } \quad \text { A ( solid) } \longrightarrow \text { B (char) + C1 (gas) } \\
& \text { Second stage: B (char) } \longrightarrow \text { C2 (gas) + D (ash) }
\end{aligned}
$$

The kinetic parameters were calculated from the linear regression curve with the correlation factors (above 0.90), based on the Arrhenius law. The activation energy (Ea) that occurs at every TD process [33-35] was determined by using the following equations:

$$
k=A e^{(-E a / R T)}
$$

where, $k$ is the reaction rate, $E a$ is the activation energy for the reaction $(\mathrm{J} / \mathrm{mol}), A$ is the pre-exponential factor $(1 / \mathrm{min}), R$ is the universal gas constant $(8.314 \mathrm{~J} / \mathrm{K} \mathrm{mol})$, and $T$ is the absolute temperature $(\mathrm{K})$. The equation can be written in logarithmic form:

$$
\ln k=\ln A-\left(\frac{E a}{R T}\right) \ln e
$$

where, $\ln \mathrm{e}=1$

$$
\ln k=-\frac{E a}{R} \times \frac{1}{T}+\ln A
$$

Based on previous studies [33, 36, 37], the Eq. (5) was obtained:

$$
\ln k=-\ln \left[\frac{\ln (1-\alpha)}{T^{2}}\right] \text { and } \ln A=\ln \frac{A R}{\beta E}
$$


Thus, Eq. (5) can be written as:

$$
-\ln \left[\frac{\ln (1-\alpha)}{T^{2}}\right]=\frac{E a}{R} \times \frac{1}{T}+\ln \frac{A R}{\beta E}
$$

where, $\beta$ is the heating rate $(\mathrm{K} / \mathrm{min})$. The mass loss fraction $\alpha$ (mg) for every stage of the thermal degradation is defined as:

$$
\alpha=\frac{M i-M a}{M i-M f}
$$

where, $M i$ is the initial mass of the sample at the beginning reaction (mg), $M a$ is the actual mass of the sample (mg), and $M f$ is the final mass, or the mass after oxidation of the sample (mg). The Ea may then be extracted from a plot of $\ln k$ vs. $1 / T$, which should be linear. Eq. (5) can be analogous to the equation of a straight line, which is often symbolized by the linear regression equationy $=\mathrm{mx}+\mathrm{b}$. Thus, the $-\ln \left[\frac{\ln (1-\alpha)}{T^{2}}\right]$ is they-axis, $\frac{1}{T}$ is the x-axis, and $b=\ln \frac{A R}{\beta E}$ is the intercept of the line with the y-axis, with $m=\frac{E a}{R}$ as slope. The $E a$ is obtained for every step of degradation (mass loss) [33, 37, 38].

\section{Results and Discussion}

Table 1 shows the results of the proximate and ultimate analyses of $(\mathrm{RH})_{\mathrm{x}}(\mathrm{PB})_{1-\mathrm{x}}(\mathrm{x}=(1,0.9,0.7,0.5))$. For $\mathrm{RH}$, it shows good agreement with previous results [38] for elemental composition (fixed carbon (FC), volatile matter (VM), ash (A) content, carbon $(\mathrm{C})$, hydrogen $(\mathrm{H})$, and oxygen $(\mathrm{O})$ ), with differences $<10 \%$. We also compared the results with several reported in previous studies [39-42] for the value of moisture content (MC), VM, $\mathrm{FC}$, nitrogen $(\mathrm{N})$, sulphur $(\mathrm{S}), \mathrm{O}, \mathrm{H}$, and $\mathrm{A}$, where the values were similar. This shows that the parameters of the test results and methodology used in this study show good accuracy, with acceptable values. The most important elements for energy application, which must be of high content, are $\mathrm{C}, \mathrm{FC}, \mathrm{H}$, and $\mathrm{MC}$, but other elements should be low. $\mathrm{PB}$ shows high $\mathrm{C}$ and $\mathrm{H}$, and low A, MC, N, O, and S; while RH shows high FC and MC. By mixture of RH and PB to form composites, a good characteristic element can be obtained for the release of energy. Table 1 shows that composites $(\mathrm{RH})_{\mathrm{x}}(\mathrm{PB})_{1-\mathrm{x}}(\mathrm{x}=(0.9,0.7,0.5))$ reveal homogeneous samples; all elemental composition is increased gradually with increasing PB content for an element with higher content in $\mathrm{PB}$, and vice versa.

For $\mathrm{C}, \mathrm{H}$, and $\mathrm{O}$, we have compared with the results of predictive equation by using data from proximate analysis as input

Table 1. Elemental Composition by Using Proximate and Ultimate Analysis, and Calorific Value from Bomb Calorimeter in Oxygen Environment for Composites $(\mathrm{RH})_{x}(\mathrm{~PB})_{1-\mathrm{x}}(\mathrm{x}=1,0.9,0.7,0.5)$. We Have Included Elemental Composition for RH from [31], Calculation Based on

\begin{tabular}{|c|c|c|c|c|c|c|c|}
\hline Parameter & Unit & RH (Present Study) & RH [31] & $10 \%$ PB & $30 \% \mathrm{~PB}$ & $50 \%$ PB & PB \\
\hline \multicolumn{8}{|l|}{ Proximate Analysis } \\
\hline Fixed carbon (FC) & (\%) & 14.81 & 16.95 & 13.62 & 10.89 & 8.00 & 0.72 \\
\hline Volatile matter (VM) & (\%) & 55.62 & 61.81 & 58.65 & 65.21 & 72.39 & 89.04 \\
\hline Moisture content (M) & (\%) & 10.46 & & 9.68 & 7.53 & 5.26 & 0.22 \\
\hline Ash (A) & (\%) & 19.11 & 21.24 & 18.05 & 16.37 & 14.35 & 10.02 \\
\hline \multicolumn{8}{|l|}{ Ultimate Analysis } \\
\hline Carbon & $(\%)$ & 37.48 & 38.50 & 40.21 & 47.00 & 53.60 & 67.49 \\
\hline Predictive [35] & $(\%)$ & 32.68 & & 33.09 & 33.97 & 35.01 & 36.76 \\
\hline Predictive [36] & $(\%)$ & 41.91 & & 42.13 & 42.49 & 42.98 & 43.57 \\
\hline Hydrogen & (\%) & 5.08 & 5.20 & 5.82 & 7.10 & 8.61 & 10.25 \\
\hline Predictive [35] & (\%) & 9.92 & & 9.69 & 8.91 & 8.11 & 6.38 \\
\hline Predictive [36] & $(\%)$ & 4.09 & & 4.28 & 4.64 & 4.98 & 0.17 \\
\hline Oxygen & (\%) & 37.81 & 34.61 & 35.45 & 29.13 & 23.08 & 11.92 \\
\hline Predictive [35] & (\%) & 51.92 & & 51.73 & 50.29 & 48.91 & 46.19 \\
\hline Predictive [36] & (\%) & 24.92 & & 26.39 & 29.56 & 33.04 & 41.08 \\
\hline Nitrogen & (\%) & 0.43 & & 0.38 & 0.31 & 0.28 & 0.26 \\
\hline Sulfur & (\%) & 0.09 & & 0.09 & 0.09 & 0.08 & 0.06 \\
\hline Ash & (\%) & 19.11 & & 18.05 & 16.37 & 14.35 & 10.02 \\
\hline \multicolumn{8}{|l|}{ Calorific and Bulk } \\
\hline Calorific value & $(\mathrm{MJ} / \mathrm{kg})$ & 13.44 & & 17.85 & 23.97 & 28.93 & 41.21 \\
\hline Predictive [37] & $(\mathrm{MJ} / \mathrm{kg})$ & 21.81 & & 22.52 & 24.01 & 25.68 & 29.31 \\
\hline Bulk density & $\left(\mathrm{kg} / \mathrm{m}^{3}\right)$ & 265 & & 228,5 & 198,8 & 167.6 & 112 \\
\hline
\end{tabular}
Predictive Equation for Carbon, Hydrogen, and Oxygen from [35, 36], and for Calorific Value from [37] for Comparison 
parameter, proposed by [43] in the form: $\mathrm{C}=-35.9972+$ $0.7698 V M+1.3269 F C+0.3250 A, \mathrm{H}=55.3678-0.4830 V M-$ $0.5319 F C-0.5600 A, \mathrm{O}=223.6805-1.7226 V M-2.2296 F C-2.2463 A$, and those proposed by [42] in the form: $\mathrm{C}=0.47 \mathrm{VM}+0.963 \mathrm{FC}$ $+0.067 A, \mathrm{H}=0.074 V M+0.012 F C-0.052(V M / F C), \mathrm{O}=0.569 V M$ $+0.010 F C-0.069 A$. The predictive proposed by Nhuchhen [43] shows reasonable agreement for $\mathrm{RH}$ with differences of about $10 \%$, while the predictive proposed by Thomas Klasson [44] shows good agreement for $10 \% \mathrm{~PB}$ in composites. The $\mathrm{C}$ content from the ultimate analysis in this study shows an increase with increasing PB content in composites that is consistent with the result from predictive equation from [43], with differences of about $15 \%$ lower than the ultimate analysis data. The predictive equation from [44] shows that $\mathrm{C}$ content is higher for $\mathrm{RH}$, and increases by about $0.5 \%$ with increasing $\mathrm{PB}$ content in composites. For $\mathrm{H}$, good agreement is shown between the predictive equation from [44] only for $\mathrm{RH}$, and from [43] only for $30 \% \mathrm{~PB}$ and $50 \% \mathrm{~PB}$, compared with the ultimate analysis data. For $\mathrm{O}$, the content shows a big difference of about $30-40 \%$ between the ultimate analysis data with predictive from [43], and good agreement only for $30 \%$ PB with the predictive from [44]. These results indicated that the existing predictive equations from [43] and [44] show good accuracy in results compared with the ultimate analysis data only for several compositions in composites RH and PB.

Table 1 shows that we compared the CV determined by bomb calorimetry in this study with the predictive model developed by Majumder et al. [45] in the form CV $(\mathrm{MJ} / \mathrm{kg})=-0.03 A-0.11 M$ $+0.33 V M+0.35 F C$. RH shows CV of about $13.44 \mathrm{MJ} / \mathrm{kg}$, which is very good agreement with [40] of about $13.30 \mathrm{MJ} / \mathrm{kg}$, and [41] of about $13.50 \mathrm{MJ} / \mathrm{kg}$; and $\mathrm{PB}$ shows CV of about 41.21 $\mathrm{MJ} / \mathrm{kg}$ in this study, which is also comparable with the previous studies [46-48]. For composites, the CV was increased by about $30 \%$ with increasing $\mathrm{PB}$ content in composites. The differences between predictive equations with the result in this study for 30 and 50\% PB in composites are about 10\%, but become high for pure $\mathrm{RH}$ and $\mathrm{PB}$. This indicated that the predictive $\mathrm{CV}$ from [45] is valid for high PB content in composites, and shows good agreement with ethanol (30 MJ/kg) and methanol (23 MJ/kg) as acceptable fuels [49].

For composites $(\mathrm{RH})_{\mathrm{x}}(\mathrm{PB})_{1-\mathrm{x}}(\mathrm{x}=(0.9,0.7,0.5))$, the CV increased with increasing amount of $\mathrm{PB}$ to $\mathrm{RH}$ from $17.85 \mathrm{MJ} / \mathrm{kg}$ for $\mathrm{x}=0.9,23.97 \mathrm{MJ} / \mathrm{kg}$ for $\mathrm{x}=0.7$, to $28.93 \mathrm{MJ} / \mathrm{kg}$ for $\mathrm{x}=$ 0.5. Moreover, increasing the CV showed a positive correlation with $\mathrm{C}, \mathrm{H}$, and VM of the fuel. In contrast, the addition of PB lowered the percentage of $\mathrm{O}, \mathrm{S}, \mathrm{N}, \mathrm{FC}, \mathrm{MC}$, and A. The physical properties of the fuel depend on the content of CV, MC, and AC that influence the energy production. The amount of MC in the fuel affected the $\mathrm{CV}$ and $\mathrm{A}$ of the combustion products [35]. One would expect the fuel mixture to have a maximum $\mathrm{CV}$ and minimum A. The energy and power that can be generated depend on the CV content in the composites for fuel.

The addition of $\mathrm{PB}$ to $\mathrm{RH}$ can improve the quality of fuel, such as increasing $\mathrm{CV}, \mathrm{C}, \mathrm{H}$, and $\mathrm{VM}$, and decreasing FC, MC, $\mathrm{S}, \mathrm{N}, \mathrm{O}$, and $\mathrm{A}$. The increasing content of $\mathrm{C}$ and $\mathrm{H}$ means a greater contribution to the energy released [35]. However, the percentage of $\mathrm{O}$ decrease in the fuel means increasing the content of $\mathrm{C}$ and $\mathrm{H}$, as well as increasing $\mathrm{CV}$ of the fuel, but $\mathrm{O}$ is required in the process of fuel combustion. The high CV can increase energy production; thus, composites in this study become attractive as an energy source. Small amounts of $\mathrm{N}$ will reduce $\mathrm{NO}_{\mathrm{x}}$ emissions in the air, while small amounts of $\mathrm{S}$ can reduce pollution and corrosion. High amounts of VM and A and low MC are important characteristics required in the process of energy production. The high amount of $\mathrm{A}$ is affected by the reduction of energy production, and an increase of handling cost for the disposal process [50]. High MC will aggravate the chemical properties of the fuel, hence complicating the process of energy production. The increasing amount of $\mathrm{PB}$ in composites resulting in decrease in the amount of $\mathrm{N}$ and $\mathrm{S}$ indicated the formation of $\mathrm{NO}_{\mathrm{x}}$ and $\mathrm{SO}_{\mathrm{x}}$ is decreased; these are both hazardous gasses, and very harmful to the environment [51-53]. Thus, the addition of $\mathrm{PB}$ into $\mathrm{RH}$ to form composites will increase energy production, and also decrease the amount of $\mathrm{MC}, \mathrm{A}, \mathrm{NO}_{\mathrm{x}}$, and $\mathrm{SO}_{\mathrm{x}}$.

Table 2 shows the elemental composition by using XRF spectroscopy after heating the composites at the temperature of $105^{\circ} \mathrm{C}$ for several hours. The main elements for ash from $\mathrm{RH}$ are $\mathrm{Si}$ and $\mathrm{K}$ of about 73.61 and $14.31 \%$, respectively, which are similar to those reported in Refs. [26, 27], and those for ash from PB are $\mathrm{Ca}$ and $\mathrm{Ti}$ of about 75.61 and $12.93 \%$, respectively, which are similar values to those reported in [54]. The composites show $\mathrm{Si}$ and $\mathrm{K}$ as the main elements of ash from $\mathrm{RH}$ decrease

Table 2. Elemental Composition by Using X-ray Fluorescence $(\mathrm{XRF})$ for Composites $(\mathrm{RH})_{\mathrm{x}}(\mathrm{PB})_{1-\mathrm{x}}(\mathrm{x}=1,0.9,0.7,0.5)$ after $105^{\circ} \mathrm{C}$ for Several Hours

\begin{tabular}{|c|c|c|c|c|c|}
\hline Element & RH & $10 \% \mathrm{~PB}$ & 30\%PB & 50\%PB & PB \\
\hline $\mathrm{Si}$ & 73.61 & 63.35 & 34.61 & 31.99 & 2.98 \\
\hline K & 14.31 & 6.81 & 4.00 & 2.40 & - \\
\hline $\mathrm{Ca}$ & 3.51 & 18.25 & 52.89 & 57.75 & 75.61 \\
\hline $\mathrm{Cl}$ & 2.78 & 2.55 & 1.64 & - & - \\
\hline Px & 2.33 & 3.84 & 0.73 & 0.57 & - \\
\hline $\mathrm{Fe}$ & 2.06 & 0.97 & - & - & - \\
\hline $\mathrm{Ti}$ & - & 1.26 & 5.57 & 6.16 & 12.93 \\
\hline $\mathrm{Mg}$ & - & - & - & - & 7.05 \\
\hline $\mathrm{Pb}, \mathrm{Zn}, \mathrm{Cr}, \mathrm{Mn}, \mathrm{Nb}, \mathrm{Mo}$, In & 1.4 & 2.97 & 0.56 & 1.13 & 1.43 \\
\hline
\end{tabular}


with increasing the amount of $\mathrm{PB}$, and similarly, the elements of ash from $\mathrm{PB}$ areincreased with increasing the amount of $\mathrm{RH}$.

TGA and DTG curves show that there is a difference between the oxidation process of $(\mathrm{RH})_{1}(\mathrm{~PB})_{1-\mathrm{x}}(\mathrm{x}=(1,0.9,0.7,0.5))$, as shown in Fig. 1. The TGA and DTG curves of $(\mathrm{RH})_{\mathrm{x}}(\mathrm{PB})_{1-\mathrm{x}}$ $(\mathrm{x}=(1,0.9,0.7,0.5))$ show the dehydration process (DP) with degradation temperature (DT) from 40 to $100^{\circ} \mathrm{C}$ and mass loss (ML) from 2.3 to $5.2 \%$, as moisture evaporation indicated the dehydration processes. The TD of composites is of two stages for $\mathrm{x} \geq 0.7$, and of three stages for $\mathrm{x}=0.5$. TD in the first zone (TDZ1) is in the range of temperature $240-360^{\circ} \mathrm{C}$ with $\mathrm{ML}$ in the range 40.4-43.7\%, while TDZ2 is in the range of temperature of $370-490^{\circ} \mathrm{C}$, with $\mathrm{ML}$ in the range $25.4-32.6 \%$. Furthermore,
TDZ3 is in the range of temperature $600-670^{\circ} \mathrm{C}$, with $\mathrm{ML}$ of about $2.8 \%$. The total $\mathrm{ML}$ during the degradation of $(\mathrm{RH})_{1}(\mathrm{~PB})_{1-\mathrm{x}}$ $(\mathrm{x}=(1,0.9,0.7,0.5))$ is in the range $71.6-79 \%$, and generated A approximately in the range $21-28.4 \%$. This shows that the addition of $\mathrm{PB}$ to $\mathrm{RH}$ influences the thermal characteristics of composites by enlarging the energy production and reducing the A residues. Table 3 shows the parameters of kinetic study for the oxidative environment of $(\mathrm{RH})_{1}(\mathrm{~PB})_{1-\mathrm{x}}(\mathrm{x}=(1,0.9,0.7$, $0.5)$ ).

Fig. 2 shows the $E a$ that occurred in the TDZ1 of the $(\mathrm{RH})_{1}(\mathrm{~PB})_{1-\mathrm{x}}$ $(\mathrm{x}=(1,0.9,0.7,0.5))$. The activation energy for the TDZ1 of $\mathrm{RH}$ of $56.49 \mathrm{~kJ} / \mathrm{mol}$ was obtained on the basis of the linear regression: $\mathrm{y}_{1}=6,794 \mathrm{x}+1.902$, with $\mathrm{R}^{2}=0.915$ for DT in the
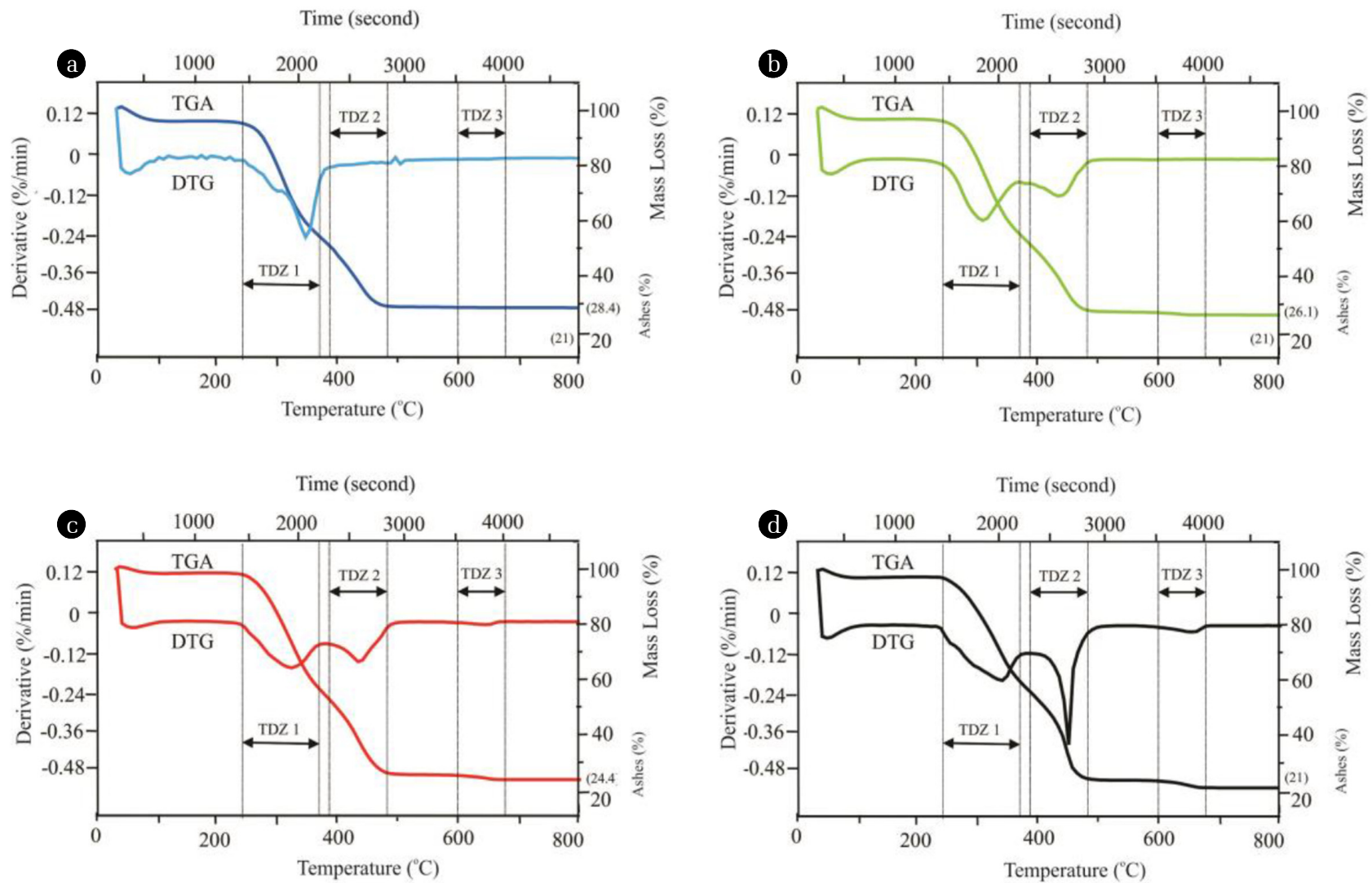

Fig. 1. TGA and DTG spectra for the temperature range $30-800^{\circ} \mathrm{C}$ with a heating rate of $10^{\circ} \mathrm{C} / \mathrm{min}$ and flow rate of air of about $50 \mathrm{~mL} / \mathrm{min}$ fromcomposites $(\mathrm{RH})_{\mathrm{x}}(\mathrm{PB})_{1-\mathrm{x}}$, for (a) $\mathrm{x}=1$, (b) $\mathrm{x}=0.9$, (c) $\mathrm{x}=0.7$, and (d) $\mathrm{x}=0.5$.

Table 3. Parameters of the Kinetic Study for the Oxidative Environment of Composites $(\mathrm{RH})_{x}(\mathrm{~PB})_{1-\mathrm{x}}(\mathrm{x}=1,0.9,0.7,0.5)$ for Thermal Degradation Zone (TDZ1, TDZ2, TDZ3) Based on Fig. 1

\begin{tabular}{|c|c|c|c|c|c|c|c|c|c|c|c|}
\hline \multirow[b]{2}{*}{ Materials } & \multirow{2}{*}{$\begin{array}{c}\text { MS } \\
\text { (mg) }\end{array}$} & \multicolumn{2}{|c|}{ DP } & \multicolumn{2}{|c|}{ TDZ1 } & \multicolumn{2}{|c|}{ TDZ2 } & \multicolumn{2}{|c|}{ TDZ3 } & \multirow{2}{*}{$\begin{array}{c}\text { EaT } \\
(\mathrm{kJ} / \mathrm{mol})\end{array}$} & \multirow{2}{*}{$\begin{array}{l}\text { Ash } \\
\text { (\%) }\end{array}$} \\
\hline & & $\begin{array}{l}\text { ML } \\
(\%)\end{array}$ & $\begin{array}{c}\mathrm{T} \\
\left({ }^{\circ} \mathrm{C}\right)\end{array}$ & $\begin{array}{l}\text { ML } \\
\text { (\%) }\end{array}$ & $\begin{array}{c}\mathrm{T} \\
\left({ }^{\circ} \mathrm{C}\right)\end{array}$ & $\begin{array}{l}\text { ML } \\
\text { (\%) }\end{array}$ & $\begin{array}{c}\mathrm{T} \\
\left({ }^{\circ} \mathrm{C}\right)\end{array}$ & $\begin{array}{l}\text { ML } \\
\text { (\%) }\end{array}$ & $\begin{array}{c}\mathrm{T} \\
\left({ }^{\circ} \mathrm{C}\right)\end{array}$ & & \\
\hline $\mathrm{RH}$ & 5.8 & 5.2 & $50-100$ & 41 & $240-360$ & 25.4 & $370-480$ & - & - & 101.22 & 28.4 \\
\hline $10 \% \mathrm{~PB}$ & 5.5 & 4.4 & $50-100$ & 43.7 & $240-360$ & 25.8 & $370-490$ & - & - & 104.03 & 26.1 \\
\hline $30 \% \mathrm{~PB}$ & 5.6 & 2.3 & $50-100$ & 42.4 & $250-380$ & 27.9 & $390-490$ & - & - & 110.95 & 24.4 \\
\hline $50 \%$ PB & 5.5 & 3.2 & $50-100$ & 40.4 & $250-380$ & 32.6 & $390-460$ & 2.8 & $600-670$ & 165.30 & 21 \\
\hline
\end{tabular}


range $240-360^{\circ} \mathrm{C}$ (Fig. 2(a)). The $E a_{1}$ of $10 \% \mathrm{~PB}$ of $55.55 \mathrm{~kJ} / \mathrm{mol}$ was based on the equation: $\mathrm{y}_{1}=6,681 \mathrm{x}+2.340$ with $\mathrm{R}^{2}=$ 0.978 for DT in the range $240-380^{\circ} \mathrm{C}$ (Fig. 2(b)). For $30 \% \mathrm{~PB}$, the $E a_{1}$ is $64.63 \mathrm{~kJ} / \mathrm{mol}$, based on the equation: $\mathrm{y}_{1}=7,774 \mathrm{x}+$ 0.721 with $\mathrm{R}^{2}=0.959$ for DT in the range $250-380^{\circ} \mathrm{C}$ (Fig. 2(c)). Furthermore, the $E a_{1}$ of $50 \% \mathrm{~PB}$ is $54.42 \mathrm{~kJ} / \mathrm{mol}$ based on the equation: $\mathrm{y}_{1}=6,546 \mathrm{x}+3.005$ with $\mathrm{R}^{2}=0.979$ for DT in the range $250-380^{\circ} \mathrm{C}$ (Fig. $2(\mathrm{~d})$ ). By the same method, Table 4 shows the equation and $E a$ for the TD process in the second (TDZ2) and the third zones (TDZ3) obtained by linear regression.

Table 4 clearly shows that the amount of PB in composites is important in increasing the $E a$ value. The higher contents of $\mathrm{PB}$ in composites are the higher values of $E a$. The oxidative process of the TD processes for $\mathrm{RH}$ was perfect after reaching a temperature of about $480^{\circ} \mathrm{C}$, and increased to $490^{\circ} \mathrm{C}$ for 10 and $30 \% \mathrm{~PB}$. For $50 \% \mathrm{~PB}$, the TD process was perfect after reaching
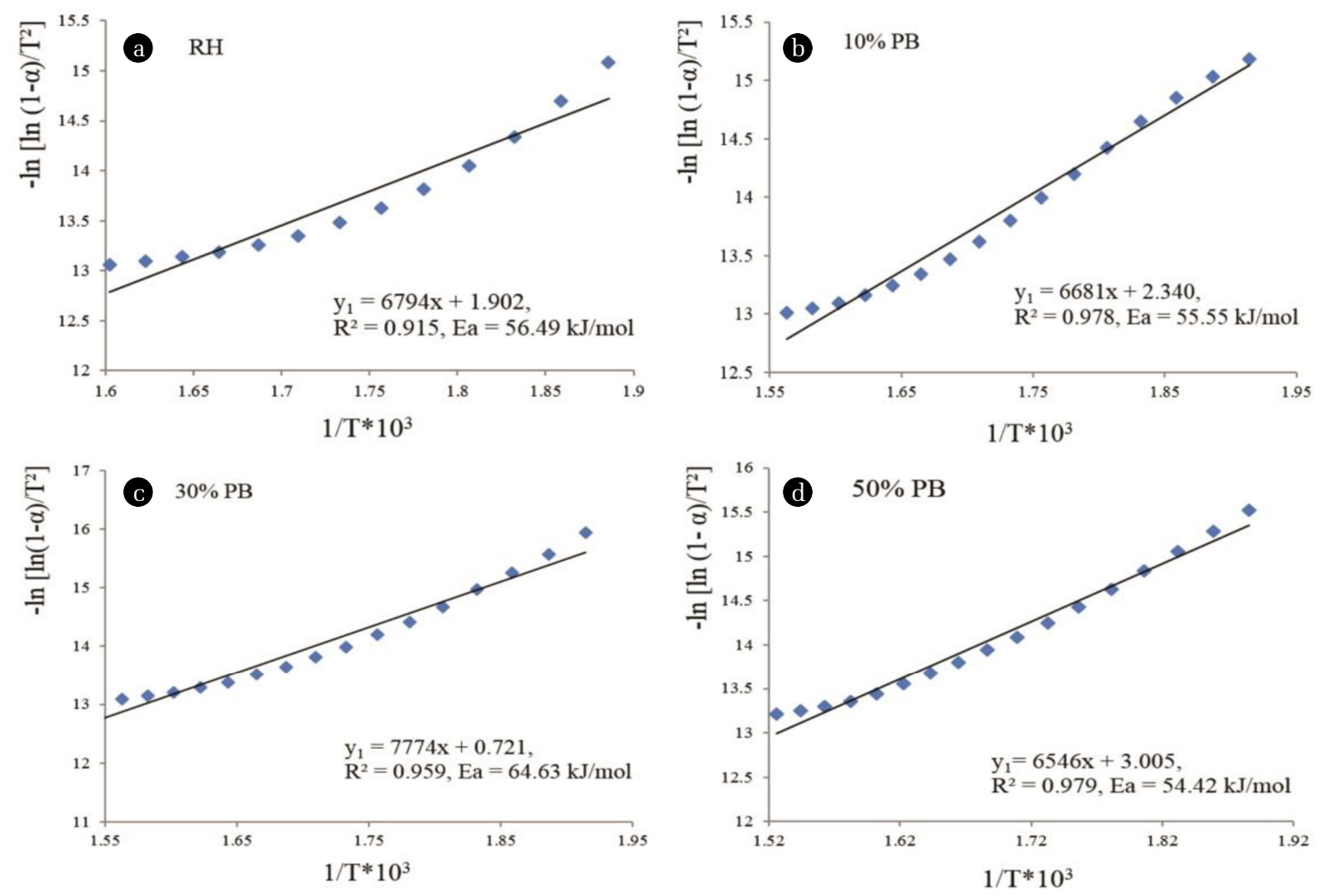

Fig. 2. The first degradation (TDZ1) stage of the oxidative process to determine activation energy $\left(E_{a}\right)$ and $R^{2}$ values from the linear regression of $-\ln \left[\ln (1-a) / T^{2}\right]$ vs. $1 / T$ for composites $(R H)_{x}(P B)_{1-x}$, for $(a) x=1,(b) x=0.9$, (c) $x=0.7$, and $(d) x=0.5$.

Table 4. Thermal Degradation Process for Zone 1, 2, 3 to Determine Activation Energy (Ea) by Using Linear Regression (as Shown in Fig. 2 for TDZ1) of Arrhenius Law from Analysis Data of TGA and DTG in Fig. 1

\begin{tabular}{|c|c|c|c|c|c|c|c|}
\hline \multirow{2}{*}{ Samples } & \multirow{2}{*}{$\begin{array}{l}\text { DT } \\
\left({ }^{\circ} \mathrm{C}\right)\end{array}$} & \multirow{2}{*}{$\begin{array}{c}\text { Linear regression of } \\
\text { Arrhenius law }\end{array}$} & \multirow{2}{*}{$\left(\mathbf{R}^{2}\right)$} & \multicolumn{4}{|c|}{ Ea $(\mathbf{k J} / \mathrm{mol})$} \\
\hline & & & & Ea1 & Ea2 & Ea3 & Total \\
\hline \multirow{2}{*}{$\mathrm{RH}$} & $240-360$ & $\mathrm{y}_{1}=6,794 \mathrm{x}+1.902$ & 0.915 & 56.49 & - & - & - \\
\hline & $370-480$ & $\mathrm{y}_{2}=5,380 \mathrm{x}+4.792$ & 0.916 & - & 44.73 & - & 101.22 \\
\hline \multirow{2}{*}{$10 \% \mathrm{~PB}$} & $240-380$ & $\mathrm{y}_{1}=6,681 \mathrm{x}+2.340$ & 0.978 & 55.55 & - & - & - \\
\hline & $390-490$ & $\mathrm{y}_{2}=5,831 \mathrm{x}+4.216$ & 0.961 & - & 48.48 & - & 104.03 \\
\hline \multirow{2}{*}{$30 \% \mathrm{~PB}$} & $250-380$ & $\mathrm{y}_{1}=7,774 \mathrm{x}+0.721$ & 0.959 & 64.63 & - & - & - \\
\hline & $390-490$ & $\mathrm{y}_{2}=5,571 \mathrm{x}+4.627$ & 0.971 & - & 46.32 & - & 110.95 \\
\hline \multirow{3}{*}{$50 \% \mathrm{~PB}$} & $250-380$ & $\mathrm{y}_{1}=6,546 \mathrm{x}+3.005$ & 0.979 & 54.42 & - & - & - \\
\hline & $390-460$ & $\mathrm{y}_{2}=6,444 \mathrm{x}+3.637$ & 0.915 & - & 53.58 & - & - \\
\hline & $600-660$ & $\mathrm{y}_{3}=6,892 \mathrm{x}+4.695$ & 0.924 & - & - & 57.30 & 165.3 \\
\hline
\end{tabular}


a temperature of about $660^{\circ} \mathrm{C}$, and from temperature in the range $660-800^{\circ} \mathrm{C}$, there was no TD or $\mathrm{ML}$. This shows that the composites $(\mathrm{RH})_{1}(\mathrm{~PB})_{1-\mathrm{x}}(\mathrm{x}=(1,0.9,0.7,0.5))$ combustion as fuel requires a temperature range of about $480-660^{\circ} \mathrm{C}$ to perform the complete combustion process to produce high energy.

\section{Conclusions}

New composites $(\mathrm{RH})_{\mathrm{x}}(\mathrm{PB})_{1-\mathrm{x}}(\mathrm{x}=1,0.9,0.7,0.5)$ have been obtained, and show gradually increased elemental composition with increasing $\mathrm{PB}$ content for an element with higher content in $\mathrm{PB}$, and decrease with increasing $\mathrm{PB}$ for lower content in $\mathrm{PB}$, indicating a homogeneous composite sample. The CV determined by bomb calorimetry shows about $13.44 \mathrm{MJ} / \mathrm{kg}$ for $\mathrm{RH}$, and about $41.21 \mathrm{MJ} / \mathrm{kg}$ for $\mathrm{PB}$, for composites, which was increased by about $30 \%$ with increasing $\mathrm{PB}$ content in composites, indicating $\mathrm{PB}$ has a strong effect on the composites.

The temperature range that produced the highest energy and performed complete combustion process of the composites $(\mathrm{RH})_{\mathrm{x}}(\mathrm{PB})_{1-\mathrm{x}}(\mathrm{x}=(1,0.9,0.7,0.5))$ is $480-660^{\circ} \mathrm{C}$. The activation energy for $\mathrm{RH}$ is $101.22 \mathrm{~kJ} / \mathrm{mol}$, which increases by (4 and 6) magnitude for $\mathrm{x}=(0.9$ and 0.7$)$, respectively, and increases remarkably to $165.30 \mathrm{~kJ} / \mathrm{mol}$ for $\mathrm{x}=0.5$. The thermal characteristics, calorific value, and elemental analysis show the activation energy, calorific content, carbon, and hydrogen content, respectively, were strongly affected by the PB content, which contributed to increasing the realized energy.

\section{Acknowledgments}

The authors would like to thank the Kementerian Ristek-Dikti, Republic of Indonesia, for financial support through the Post-Doctoral Program, 2017.

\section{References}

1. Qodri FE, Widodo WP, Mahmud S, Akhmad H. An assessment of Indonesia's energy security index and comparison with seventy countries. Energy 2016;111:364-376.

2. Tobias SS, Nicola UB, Ratri SW. Attracting private investments into rural electrification - A case study on renewable energy based village grids in Indonesia. Energy Sust. Dev. 2013;17:581-595.

3. Friederich MC, Moore TA, Flores RM. A regional review and new insights into SE Asian Cenozoic coal-bearing sediments: Why does Indonesia have such extensive coal deposits? Int. J. Coal Geol. 2016;166:2-35.

4. Anshar M, Kader AS, Ani FN. The utilization potential of rice husk as an alternative energy source for power plants in Indonesia. Adv. Mater. Res. 2014;845:494-498.

5. Nicola UB, Ratri SW, Tobias SS. Rural electrification through village grids - Assessing the cost competitiveness of isolated renewable energy technologies in Indonesia. Renew. Sust.
Energy Rev. 2013;22:482-496.

6. Zhao B, Li BX. The effect of sodium chloride on the pyrolysis of rice husk. Appl. Energ. 2016;178:346-352.

7. Al-Amsyar SM, Adam F, Eng-Poh N. Aluminium oxide-sili$\mathrm{ca} /$ carbon composites from rice husk as a bi-functional heterogeneous catalyst for the one-pot sequential reaction in the conversion of glucose. Surface. Interface. 2017;9:1-8.

8. Touhami D, Zhu Z, Balan WS, Janaun J, Haywood S, Zein $\mathrm{SH}$. Characterization of rice husk-based catalyst prepared via conventional and microwave carbonization. J. Environ. Chem. Eng. 2017;5:2388-2394.

9. Budarin VL, Zhao Y, Gronnow MJ, et al. Microwave-mediated pyrolysis of macro-algae. Green Chem. 2011;13:2330.

10. Chen WH, Ye SC, Sheen HK. Hydrolysis characteristics of sugarcane bagasse pretreated by dilute acid solution in a microwave irradiation environment. Appl. Energ. 2012;93: 237-244.

11. Zhu Z, Macquarrie DJ, Simister R, Gomez LD, Mason SJM. Microwave assisted chemical pretreatment of Miscanthus under different temperature regimes. Sust. Chem. Process. 2015;3:1-13.

12. Madhiyanon T, Sathitruangsak P, Soponronnarit S. Co-combustion of rice husk with coal in a cyclonic fluidized-bed combustor ( $\psi$-FBC). Fuel 2009;88:132-138.

13. Kapur T, Kandpal TC, Garg HP. Electricity generation from rice husk in Indian rice mills: Potential and financial viability. Biomass Bioenerg. 1996;10:393-403.

14. Liu J, Wang S, Wei Q, Yan S. Present situation, problems and solutions of China's biomass power generation industry. Energ. Policy 2014;70:144-151.

15. Aretha A, Tetsuo T, Gert S. Inorganic and hazardous solid waste management: Current status and challenges for Indonesia. Procedia Environ. Sci. 2013;17:640-647.

16. Yeny D, Yulinah T, Sony S. Community participation in household solid waste reduction in Surabaya, Indonesia. Resour. Conserv. Recy. 2015;102:153-152.

17. Lino FAM, Ismail KAR. Analysis of the potential of municipal solid waste in Brazil. Environ. Dev. 2012;4:105-113.

18. Zhou C, Fang W, Xu W, Cao A, Wang R. Characteristics and the recovery potential of plastic wastes obtained from landfill mining. J. Clean. Prod. 2014;80:80-86.

19. Wong SL, Ngadi N, Abdullah TAT, Inuwa IM. Current state and future prospects of plastic waste as source of fuel: A review. Renew. Sust. Energ. Rev. 2015;50:1167-1180.

20. Tabasová A, Kropáč J, Kermes V, Nemet A, Stehlík P. Waste-to-energy technologies: Impact on environment. Energy 2012;44:146-155.

21. Othman MR, Martunus, Zakaria R, Fernando WJN. Strategic planning on carbon capture from coal-fired plants in Malaysia and Indonesia: A review. Energ. Policy 2009;37:1718-1735.

22. Chen D, Zheng Y, Zhu X. In-depth investigation on the pyrolysis kinetics of raw biomass. Part I. Kinetic analysis for the drying and devolatilization stages. Bioresour. Technol. 2013;131:40-46.

23. Xie Z, Ma X. The thermal behavior of the co-combustion between paper sludge and rice straw. Bioresour. Technol. 2013;146:611-618. 
24. Hiloidhari M, Baruah DC. Crop residue biomass for decentralized electrical power generation in rural areas (part 1): Investigation of spatial availability. Renew. Sust. Energ. Rev. 2011;15:1885-1892.

25. Hiloidhari M, Baruah DC. Rice straw residue biomass potential for decentralized electricity generation: A GIS-based study in Lakhimpur district of Assam, India. Energ. Sust. Dev. 2011;15:214-222.

26. Maiti S, Dey S, Purakayastha S, Ghosh B. Physical and thermochemical characterization of rice husk char as a potential biomass energy source. Bioresour. Technol. 2006;97:2065-2070.

27. Shen J, Zhu S, Liu X, Zhang H, Tan J. Measurement of heating value of rice husk by using oxygen bomb calorimeter with benzoic acid as combustion adjuvant. Energy Procedia 2012;17:208-213

28. Chakraverty A, Mishra P, Banerjee HD. Investigation of thermal decomposition of rice husk. Thermochim. Acta 1985;94: 267-275.

29. Hanna SB, Farag LM. Kinetic studies on thermal degradation of treated and untreated rice husk. Thermochim. Acta 1985;87:239-247.

30. James J, Rao MS. Silica from rice husk through thermal decomposition. Thermochim. Acta 1986;97:329-336.

31. Vlaev LT, Markovska IG, Lyubchev LA. Non-isothermal kinetics of pyrolysis of rice husk. Thermochim. Acta 2003;406:1-7.

32. Biagini E, Fantei A, Tognotti L. Effect of the heating rate on the devolatilization of biomass residues. Thermochim. Acta 2008;472:55-63.

33. Shen DK, Gua S, Luo KH, Bridgwater AV, Fang MX. Kinetic study on thermal degradation of woods in an oxidative environment. Fuel 2009;88:1024-1030.

34. Chin BLF, Yusup S, Shoaibi AA, Kannan P, Srinivasakannan C, Sulaiman SA. Kinetic studies of co-pyrolysis of rubber seed shell with high-density polyethylene. Energ. Convers. Manage. 2014;87:746-753.

35. Sait HH, Hussain A, Salema AA, Ani FN. Pyrolysis and combustion kinetics of date palm biomass using thermogravimetric analysis. Bioresour. Technol. 2012;118:382-389.

36. Boxiong S, Qinlei. Study on MSW catalytic combustion by TGA. Energ. Convers. Manage. 2006;47:1429-1437.

37. Leroy V, Cancellieri D, Leonib E, Rossib JL. Kinetic study of forest fuels by TGA: Model-free kinetic approach for the prediction of phenomena. Thermochim. Acta 2010;497:1-6.

38. Aboyade AO, Hugo TJ, Carrier M, et al. Non-isothermal kinetic analysis of the devolatilization of corn cobs and sugarcane bagasse in an inert atmosphere. Thermochim. Acta 2011;517: 81-89.

39. Shen J, Zhu S, Liu X, Zhang H, Tan J. The prediction of elemental composition of biomass based on proximate analysis. Energ. Convers. Manage. 2010;51:983-987.
40. Rozainee M, Ngo SP, Salema AA, Tan KG. Computational fluid dynamics modeling of rice husk combustion in a fluidized bed combustor. Powder Technol. 2010;203:331-347.

41. Ghani WA, Alias AB, Savory RM, Cliffe KR. Co-combustion of agricultural residues with coal in a fluidized bed combustor. Waste Manage. 2009;29:767-773.

42. Kuprianov VI, Janvijitsakul K, Permchart W. Co-firing of sugar cane bagasse with rice husk in a conical fluidized-bed combustor. Fuel 2006;85:434-442.

43. Nhuchhen DR. Prediction of carbon, hydrogen, and oxygen composition of raw and terrified biomass using proximate analysis. Fuel 2016;180:348-358.

44. Klasson KT. Biochar characterization and a method for estimating biochar quality from proximate analysis results. Biomass Bioenerg. 2017;96:50-58.

45. Majumder AK, Jain R, Banerjee P, Brnwal IP. Development of a new proximate analysis based correlation to predict calorific value of coal. Fuel 2008;87:3077-3081.

46. Kumar S, Singh RK. Pyrolysis kinetics of waste high-density polyethylene using thermogravimetric analysis. Int. J. Chem. Tech. Res. 2014;6:131-137.

47. Adrados A, de Marco I, Caballero BM, López A, Laresgoiti MF, Torres A. Pyrolysis of plastic packaging waste: A comparison of plastic residuals from material recovery facilities with simulated plastic waste. Waste Manage. 2012;32:826-832.

48. Chattopadhyay J, Kim C, Kim R, Pak D. Thermogravimetric characteristics and kinetic study of biomass co-pyrolysis with plastic. Korean J. Chem. Eng. 2008;25:1047-1053.

49. NPL National Physics Laboratory. Calorific values of solid, liquid and gaseous fuels [Internet]. E.F.G. Herington: NPL National Physics Laboratory; 1995 [cited 12 December 2017]. Available from: http://www.kayelaby.npl.co.uk/chemistry/3_ 11/3_11_4.html.

50. Tsuchiya Y, Yoshida T. Pelletization of brown coal and rice bran in Indonesia: Characteristics of the mixture pellets including safety during transportation. Fuel Process. Technol. 2017;156:68-71.

51. Burgard DA, Bria CRM. Bridge-based sensing of $\mathrm{NO}_{\mathrm{x}}$ and $\mathrm{SO}_{2}$ emissions from ocean-going ships. Atmos. Environ. 2016;136:54-60.

52. Sung Y, Lee S, Kim C, et al. Synergistic effect of co-firing woody biomass with coal on $\mathrm{NO}_{\mathrm{x}}$ reduction and burnout during air-staged combustion. Exp. Therm. Fluid Sci. 2016;71:114-125

53. Fan W, Li Y, Guo Q, Chen C, Wang Y. Coal-nitrogen release and $\mathrm{NO}_{\mathrm{x}}$ evolution in the oxidant-staged combustion of coal. Energy 2017;71:417-426.

54. Andrew TT, Montserrat F. Field-portable-XRF reveals the ubiquity of antimony in plastic consumer products. Sci. Total Environ. 2017;584:982-989. 